\title{
Landscape services: the concept and its practical relevance
}

\author{
Olaf Bastian - Karsten Grunewald - \\ Ralf-Uwe Syrbe - Ulrich Walz - Wolfgang Wende
}

Received: 18 December 2013/Accepted: 28 Junc 2014/Published online: 15 July 2014

(C) Springer Science+Business Media Dordrecht 2014

\begin{abstract}
Recently, in addition to the popular concept of "ecosystem services" (ES), the term "landscape services" (LS) has come into use. We are examining the question of whether a stronger focus on LS would be useful. particularly with regard to case studies carried out in Germany. Important reasons for introducing the term LS include the prominent role of spatial aspects, the reference to landscape elements and the landscape character, and the relevance of LS for landscape planning. We found no strong arguments for replacing the concept of ES by LS; however, we do prefer a situatior-related use of both concepts. We propose the following definition: Landscape services are the cortributions of landscapes and landscape elements to human well-being.
\end{abstract}

\footnotetext{
O. Bastian $(\square)$ - K. Grunewald R.-U. Syrbe

U. Walz . W. Wende

Leibniz Institute of Ecological Urtan and Regional

Development, Weberplatz 1. 01217 Dresden, Germany

c-mail: o.bastian@ioer.de; olaf.bastian@wcb.dc

K. Gruncwald

c-mail: k.grunewald@ioer.dc

R.-U. Syrbc

e-muil: r.sybte@ ioer.de

U. Walz

e-mail: u.walz@jocr.de

W. Wende

c-mail: w.wende@iner.de
}

Keywords Landscape elements - Landscape character - Spatial reference units - Landscape planning and management

\section{Introduction}

In addition to the term and concept of ecosystem services (ES), which has become very popular over the past few years, a similar term has increasingly come into use: landscape services (LS). Arguments for its significance (e.g. Burkhard et al. 2009; Termorshuizen and Opdam 2009; Grunewald and Bastian 2010, 2013; Kienast 2010; Frank et al. 2012; Syrbe and Walz 2012; Willemen et al. 2012; $\mathrm{Wu} 2013$ ) include its spatial aspects, its more contextual view, the greater role it assigns to human-influenced areas, its practical applicability, and particularly its great relevance for participatory landscape planning

Here we examine the definition of LS, and address the question of whether and in which cases LS are more suitable than ES. We will review the arguments for LS from the literature, especially from Termorshuizen and Opdam (2009), and add new ones, particularly referring to service-providing landscape elements, the role of landscape units as spatial reference units, and the landscape character. We will analyze cases in which it might he helpful to speak of LS (in addition to or instead of ES). The pros and cons of LS and its practical application will be shown through several examples from Germany. 
We start with a brief comparison between the concepts of ecosystem and landscape. Then, we will discuss a number of arguments for LS, illustrated by case studies, including:

(1) The appreciation of landscape attributes by tourists,

(2) Ecological risks caused by intensive agriculture,

(3) Historical landscape elements,

(4) Agro-environmental measures in a landscape plan, and

(5) Landscape management accounting.

We do not give examples for spatial aspects of LS (or ES), because an extensive literature on this topic already exists (e.g. Blaschke 2006; Hein et al. 2006; Costanza 2008; Fisher et al. 2009; de Groot et al. 2010; Bastian et al. 2012a).

Building upon the statements and lessons learned as described in the case studies, we will examine to which extent and in which cases ES may or should he defined as LS. The services are named, briefly defined and demonstrated using examples and indicators. By means of a three-stage scale (low-medium-high), the relevance of the services to the following four criteria will be assessed: spatial aspects (e.g. patterns), landscape character (peculiarity), reference to landscape elements or entire landscapes, and relevance for landscape planning.

Finally, we will give a comprehensive overview of special features of LS (an updated list of arguments for using the term LS comparing with ES), briefly address the question of special tools (frameworks) and propose a definition of $L S$.

\section{Ecosystem and landscape}

An ecosystem encompasses the structure of interrelationships of living beings to one another. and to their inorganic environment (CBD 1992). Ellenberg (1973) characterized "ecosystem" by the long-term relationship between a biocenosis and its habitat (biotope).

Admittedly, landscape is ambiguously defined; the term is controversial, and there is to this day no consensus on its contents. Rather, a number of quite different interpretation patterns exist, and the term "landscape" covers a broad spectrum of meanings and contexts, differing between languages, cultural and academic backgrounds, levels of education, socialization, and interest groups (Palang et al. 2006). Leibenath and Gailing (2012) distinguish between four main approaches to define "landscape": (1) as a physical space or ecosystem complex; (2) in the context of relationships between humankind and the environment; (3) as a metaphoric expression; and (4) as a social construction, or a term in everyday discourse.

We define landscape as a part (at various scales) of the earth's surface, which is shaped by natural conditions and formed by human influences to a different extent. It is perceived and felt by humans as characteristic, and it can be differentiated and classified according to defined rules (Bastian 2008). With respect to the introduction of the term "landscape services", Termorshuizen and Opdam (2009) stressed the role of landscapes as "spatial human-ecological systems that deliver a wide range of functions that are or can be valued by humans for economic, sociocultural, and ecological reasons."

In the context of LS as discussed here, we consider physical definitions of "landscape" particularly important, without denying the meaningtulness of other landscape concepts. The attractiveness of the landscape approach results to a great extent from the fact that it contains natural, cultural and utility aspects alike, and sees the landscape as a hybrid system, with the interplay of nature, society and technology (e.g. Neef 1976. Hein et al. 2006). "Landscape" highlights "the importance of spatial patterns, whereas the ecosystem concept highlights the functional (vertical) relationship between ecosystem components" (O'Neill 2001 in Termorshuizen and Opdam 2009), however, without excluding spatial aspects completely.

In short, the unique characteristics of "landscape", as compared to "ecosystem", are, first, the explicit spatial dimension, second, the stronger focus on human habitat and human action, and third, its character as at least partially a product of the human mind and communication-hence, not only a material phenomenon.

\section{Landscape services: specific features, and applications}

Spatial aspects

Many ES are influenced by the landscape structure, e.g. the position of ecosystems, functional traits, landscape elements or land use units in the space in 
question. According to Willemen et al. (2012) the pattem of multifunctional landscapes is the basis for interactions, synergies or conflicts that may occur between landscape functions. The core message of landscape ecology is that landscape patterns matter to the functioning of a landscape. Moreover, the provision of services does not always depend so much on the properties of each specific, small ecosystem patch, but rather on the spatial interaction, flows and fluxes between these patches and between patches and human elements (Termorshuizen and Opdam 2009). Frank et al. (2012) argue that for a more realistic and holistic appraisal of ES provision, the "additional benefit from the pattem of various ecosystems or land cover types on landscape scale (i.e. landscape structure) must be taken into account."

Important spatial aspects which have been mentioned (e.g. Ring et al. 2010; Bastian et al. 2012a; Syrbe and Walz 2012; Willemen et al. 2012) include:

- The position or pattern of ecosystems, land cover units, landscape elements and also Service Providing Areas (SPA) and Service Benefiting Areas (SBA), and their spatial interactions

- The role of the matrix within which ecosystems and landscape elements are embedded

- The spatial intersection of biotic (e.g. vegetation) and abiotic (e.g. soil) factors

- Habitat connectivity

- The spatial requirements (i.e. minimal areas) of ecosystems to deliver specific ES (e.g. the minimum size of a catchment to be able to recharge enough groundwater for the supply of adequate amounts of drinking water, or the size of a forest effective for influencing the microclimate in the vicinity)

- The different scales on which ecosystems and landscapes can be defined

Spatial aspects can he characterized and quantified favourably by landscape (structure) metrics, e.g. in terms of the ecological functioning and the aesthetic value of a region (Walz 2008; Lang et al. 2009; Uuemaa et al. 2009; Frank et al. 2012). By means of landscape metrics, the composition and configuration of landscapes can be described mathematically in terms of such features as size, shape, number, type and arrangement of landscape elemerts. Landscape metrics are now finding their way into such practical applications as assessment procedures for landscape planning (Botequilha Leitâo et al. 2006) or recognizing and monitoring landscape changes (Heinz Center 2008, Uuemaa et al. 2009; Walz 2008, 2011).

Landscape character, reference units

The holistic paradigm (rooting on Aristotle) "the whole is more than the sum of its parts" is a basic principle of landscape ecology and applies, too, to the provision of services. The landscape matrix determines the role of each component, rather than simply constituting an addition of the components (Vandewalle et al. 2008). Willemen's (2010) stated reason for specifically addressing landscapes, e.g. for the assessment of services, rather than ecosystems is that landscapes are, in her view, spatial systems in which humans interact with their environment. In particular, the geographical context and the character of the landscape can be very important for ES (and hence for LS).

Landscape character is also reflected in landscape units as a specific type of spatial reference units which is useful, e.g. for the sampling, analysis and assignment of data, as well as for the assessment and management of ES (Bastian et al. 2006a). Several (mainly German) landscape-ecological approaches differentiate between biophysical units and landscape units. The "natural" or "biophysical unit" (German: Naturraum) is an area of land (a section of the earth's land crust) characterized by a uniform structure determined by natural laws and by a complex of abiotic (geological and geomorphologic structure, soil, water, climate) and biotic (flora and vegetation, fauna) components; it represents the relationship (in terms of processes) between geosphene and biosphere (Haase and Mannsfeld 2002). There are also several other names for such entities, e.g. geocomplex. natural complex. natural sphere, geochore. land unit. land system, ecoregion. Accordingly, Christian (1958, in Baja et al. 2002) defined land units as "parts of the land surface that can be identified as having a similar genesis and can be described similarly in terms of the major inherent features of consequence to land usenamely topography, soils, vegetation, and climate." These units can be used as the basis of field investigation, data collection, and subsequently as a decision criteria in the evaluation procedure.

Landscape units have a uniform or similar overall character, which can be favourable to attribute tailored guidelines and measures for an effective and at the same time gentle use by society. To a certain degree 
Table 1 Examples for historical landscape elements (HLE): categories and types (from Walz ct al. 2010; Bastian et al. 2013b)

\begin{tabular}{ll}
\hline HLE categorics & HLE types (cxamples) \\
\hline $\begin{array}{l}\text { Agriculture } \\
\text { Forestry }\end{array}$ & $\begin{array}{r}\text { Vincyards, meadows with scattered fruit trees, hedges, stone ridges, } \\
\text { old agricultural field terraces, wet or damp meadows, heathlands } \\
\text { Pastoral woodlands }\end{array}$ \\
$\begin{array}{l}\text { Sett]ement types } \\
\text { Traffic }\end{array}$ & $\begin{array}{l}\text { Single-street villages, scattered settlements } \\
\text { Mining }\end{array}$ \\
$\begin{array}{l}\text { Punken pathways, tree-lined avenues, narrow gauge railways } \\
\text { Military, security, administration and } \\
\text { representation }\end{array}$ & $\begin{array}{l}\text { Relics of old ore or coal mines, relics of peat cuts, former stone or chalk quarries } \\
\text { Building types }\end{array}$ \\
$\begin{array}{l}\text { Religion and water mills } \\
\text { Fishery and hunting }\end{array}$ & Buildings in the local architectural style, manor houses \\
\hline
\end{tabular}

they can also be used-as it is also possible between ecosystems of the same type-for transferring ecological data and analyses (including the capacity to supply goods and services) from a particular reference unit to ecologically similar and therefore comparable units, especially to bridge data bottlenecks.

For various ES, landscape character, which is connected to regional identity, is significant, e.g. in the context of landscape related tourism (case study 1). Examples for the successful application of landscape units include a recent project in the landscape programme of Saxony for the characterization and description of the identity of landscape regions (case study 3), and one in the landscape management strategy of Saxony for the regional differentiation of the results and needs of nature conservation measures (case study 5). The identification of areas (landscape units) in which energy crops are both viable and environmentally acceptable may help to foster the environmentally sound use of renewable energies (case study 2).

\section{Landscape elements}

Ecosystems are often understood as "natural entities", which can be analyzed by the methods of natural sciences, rather than as socio-ecological systems that include human activities (Plieninger et al. 2010). They are also sometimes (e.g. in MEA 2005) perceived as more or less unspoilt nature, with natural biodiversity and undisturbed natural processes. In most parts of the earth, however, natural ecosystems have been transformed to human-influenced ones, to cultural landscapes and landscape elements which incorporate not only natural but also cultural aspects. Of course, the ES concept also takes cultural aspects into account, as "the nonmaterial benefits people obtain from ecosystems through spiritual enrichment, cognitive development, reflection, recreation, and aesthetic experiences" (MEA 2005), but in the landscape concept such aspects are more in the foreground.

Many ecosystems (in cultural landscapes) have been changed drastically by human activities, but they can be strongly affected by heritage aspects, historical conditions and even cultural specifics, which can hardly be subsumed under the term "ecosystems". Such aspects may be more significant than ecological ones. Furthermore, there are elements in cultural landscapes, which cannot be regarded as ecosystems, e.g. buildings or technical facilities (see Table 1), sometimes the boundary is blurred, however.

Case study 3 refers to the landscape programme of Saxony recently being developed, where the landscape character based on the regional equipment with historical landscape elements (HLEs) was addressed. HLEs represent a specific, historically developed and recently diminishing sub-category of landscape phenomena which document the cultural and economic life of former human generations. As relics, they may recall memorable events, or they may mark old trade routes or former borders, e.g. court lime trees, hedges, stone walls, and milestones. They may also bear witness to former economic systems, e.g. settlement and field forms, meadow orchards, vineyards, pollarded willows, 
or fish ponds (Tahle 1). HLEs can deliver or support such important socio-cultural services as aesthetic values, identification of local people with their homeland, or recreation and ecotourism. They also serve as the basis for intellectual and artistic inspiration.

There are not only single HLEs, but also entire Iraditional landscapes which represent a specification of cultural landscapes, where historical structures have not been removed or overshadowed by contemporary, modern methods of land use, and where many relics of the past have survived to this day (Gunzelmann 1987; Antrop 2000).

\section{Landscape planning and landscape management}

The landscape concept is more relevant for planning, because in general the public has a better idea of it than it does of ecosystems. For decades, landscape planning has existed as an ecological-aesthetic planning process to maintain and develop landscape at various scales, with its functions, though without explicitly using the term ES or LS. The focus of landscape planning in Germany is the preservation and regeneration of landscape with its typical biodiversity and landscape functions, such as soils, water cycles, bio-climate, and the typical scenery (landscape aesthetic and recreational values) (von Haaren 2004). The key issue is the degree to which landscapes can be used without impairing or losing important functions or services. Depending on their particular properties, landscapes show specific and quite varying prerequisites to supply services or to withstand external threats. The inherent concem of landscape planning is to take the complexity of its object into consideration but not to treat the single components and objects of protection in isolation. Albert et al. (2012) note a growing recognition of the fact that the sensible integration of the ES concept into landscape planning would broaden the planning scope towards quantification and economic valuation.

The landscape-not the ecosystem - is also a framework for public participation and decision-making which allows a multifude of local stakeholders to participate in the identification and implementation processes regarding the landscapes they create and enjoy (Wascher 2005). Landscape conveys identity, and it is a field of action, it is people's local environment, the place where they live and work and for which they are responsible. According to Termorshuizen and Opdam (2009), it is "the detailed pattern of landscape elements that the locals perceive, valuate and manage." They also point out that LS is "more appropriate as a unifying concept than ES", first, between scientists and scientific disciplines, and second, between scientists and local actors. The landscape concept may be appealing to non-ecological scientific disciplines, particularly the social sciences. Moreover, it is also a marketing tool with respect to components related to aesthetics and perception (i.e. "selling" a region as a good place for recreation, living or working; or supporting rural development) (Wascher 2005).

In practice, many of these aspects are covered by landscape planning. At present, the practical implementation of landscape plans in Germany, however, is not satisfactory (Wende et al. 2012). One of the main reasons is that the interests and economic objectives of land users are not sufficiently taken into consideration. A comprehensive concept of landscape protection and development will also require socio-economic analyses (case study 4). The results of this case study also showed that the acceptance of landscape planning and nature conservation in rural areas can be increased by considering socio-economic issues, and thus ES or LS. On the one hand, the landscape character plays an important role (because it is the basis for designing landscape specific measures by the landscape plan), on the other hand, ecosystems are addressed to a great extent. Hence, we may use the term LS, but not necessarily.

The same applies for case study 5, the landscape management accounting for the German State of Saxony (Grunewald et al. 2014). Since in case study 5 services delivered by landscape elements and landscape units and the landscape character are involved, the term LS is justified. Those services with a clear relationship to landscape (e.g. pattern, landscape character) can be regarded as LS.

\section{Case studies}

In the following, several case studies from Saxony (Germany) shall underpin and illustrate the theoretical considerations in an exemplary manner.

Case study 1: The appreciation of landscape attributes by tourists

Landscape visual aesthetic quality is a joint product of particular visible features of the landscape interacting 
with relevant psychological processes in a human observer (Daniel 2001). A survey on the appreciation of landscape scenery was carried out among visitors and tourist service providers in the EibenstockCarlsfeld region in the Western Ore Mountains of Saxony (Germany). Via interviews, we queried the valuation of certain scenery's characteristics, and we analysed the survey results using the travel costs and willingness-to-pay methods. The study comprised face-to-face interviews with 95 summer and 105 winter tourists. The aim was the analysis and monetary valuation of socio-cultural ecosystem service related to landscape aesthetics in order to give foundations for improved landscape planning and management.

The tourists surveyed assigned particularly high aesthetic values to visible near-natural landscape elements such as wood and water bodies as well as to their harmonic composition. More than $60 \%$ of the tourists assigned greater significance to the interaction of landscape attributes, i.e. to the overall landscape character, than to single attributes (approx. $40 \%$ ). An undisturbed landscape was the principal reason for travelling to the region and spending holidays there. Altogether, tourists pay about 5.5 Mio $\boldsymbol{E}$ per year for travel costs (extrapolated to the total number of tourists visiting the region), and additionally they would be willing to pay $170 \mathrm{~T} \epsilon$ in addition for the protection and management of valuable ecosystems and the landscape. The results show that the visitors highly value public goods and services, which have to be considered more strongly in future planning (Grunewald et al. 2012).

Furthermore it became clear, that such services like aesthetics, spiritual or recreational ones should be seen only in a spatial (landscape) context. For example, an aesthetic value results from the specific combination of elements at a particular place.

Case study 2: Ecological risks caused by intensive agriculture

The increased cultivation of energy crops has a variety of economic, social and environmental effects, including manifold implications for LS. as we could show by means of a case study in the Saxon district of Gorlitz (Lupp et al. 2011: Bastian et al. 2013a). We started with an indicator-based analysis of the present state of services (supply) and interpreted the results in light of an ecological risk assessment for the present situation and for three different future scenarios. It was possible to refer the results to spatial reference units (physical landscape units), and to reveal spatial differences in carrying capacity (Rosenberg et al. 2014). We used as a specific type of landscape units so-called micro-chores, which are mosaics of $80-100$ geotopes. A geotope is defined as the elementary physio-geographical unit, homogeneous in terms of particular structures (pattern) and processes (Leser 1997). These micro-chores have an average size of $12 \mathrm{~km}^{2}$, and are characterized by the following key indicators: geological-structural unit, meso-relief mosaic type, soil form combination. hydromorphic area type, macro-climate, and altitude zone.

To obtain an overall risk assessment for a bundle of selected services, the sum of particular risks was calculated, these being the following aspects: erosion (both water and wind), nitrate leaching, losses in groundwater recharge and carbon sequestration, reduced biotope function, and decreasing landscape aesthetic value (Fig. 1). It is obvious that the overall risks for a bundle of LS caused by intensified agriculture differs significantly within the study area depending on the peculiarities of (physical) landscape units (micro-chores). The demand side was assessed on the basis of semi-structured interviews and standardized questionnaires (Lupp et al. 2014).

As in these both case studies complex structures and the context on the landscape level (landscape character) are decisive for the assessment, it is justified to use the term LS instead of ES.

Case study 3: Historical landscape elements (HLEs)

Historical landscape elements are an important part of cultural landscapes and the services they deliver (e.g. Tveit et al. 2006). Therefore inventories of HLEs and the characterization of historical cultural landscape are carried out in several states (Burggraaff and Kleefeld 1998; The Countryside Agency + Scottish Natural Heritage 2002). For the landscape programme of Saxony, a new multistage methodology was developed by Walz et al. (2010), Bastian et al. (2013b) for analyzing and evaluating HLEs and entire landscapes. This approach combines methods of spatial analyses of geodata, descriptive statistics and spatial and hierarchical clustering. The goal was to derive cultural landscape units and to assess the different units by their configuration of typical HLEs. 


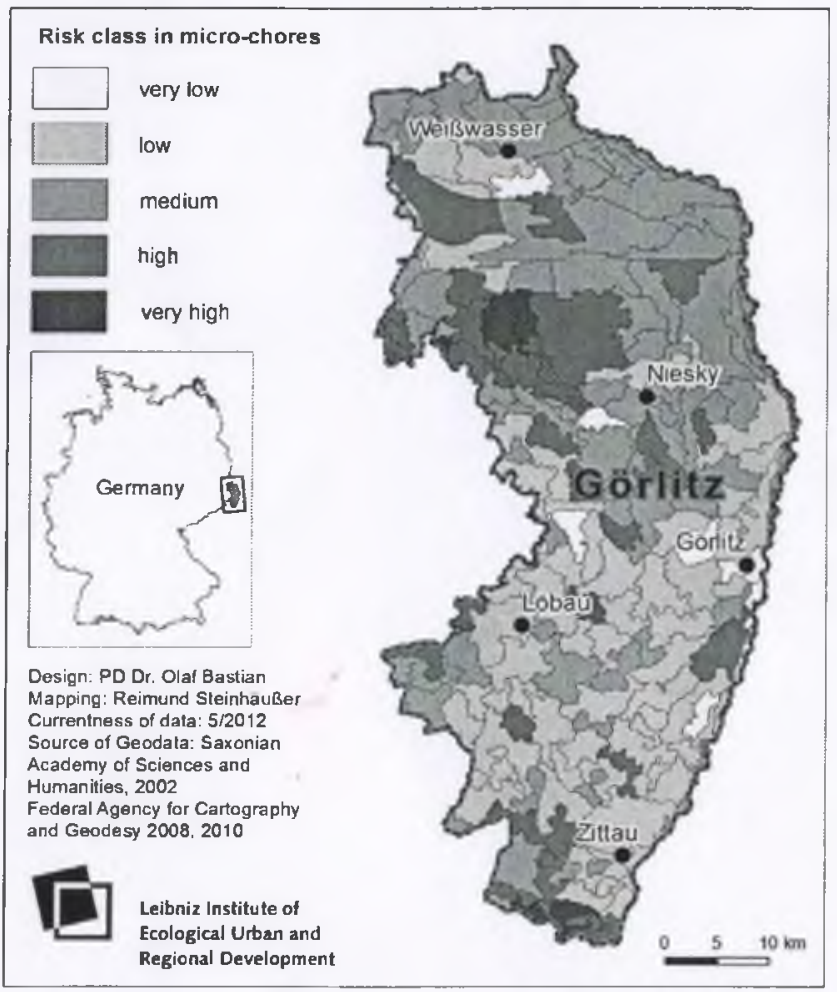

Fig. 1 Overall risk faced by a bundle of LS caused by increased energy crop cultivation, hased on landscape units (micro-chores) in the districe of Gorlitz (Saxony, Germany). For example "very high" indicates very high risks for LS caused by encrgy crops

In the first step, the different HLEs (Table 1) were mapped into a digital spatial database. The processing with the aid of a GIS enabled the classification of the frequencies of element types per local landscape units. In the second step, the distribution of every single HLE type was grouped by the method of hot spot analysis. This results in complex units characterized by the specific HLE. In the third step, cultural landscape areas that differ in their diversity and character shaped by HLE were established by aggregating similarly structured units with a cluster analysis. In the fourth step, the local landscape units were assessed with regard to the degree in which they are marked by particular HLE types (Fig. 2), and priority areas for preservation of historical landscape character were derived. The figure shows that there are landscape units, which are more characterized by HLEs than others. Especially in the mountainous southern part of Saxony the percentage of such landscape elements is high.

This example shows, that (in particular cultural) services notably result not only from ecosystems but from cultural elements. These can be both "living" elements like hedges, orchards or semi-natural meadows created by humans, and cultural artefacts like buildings, memorials, etc. 


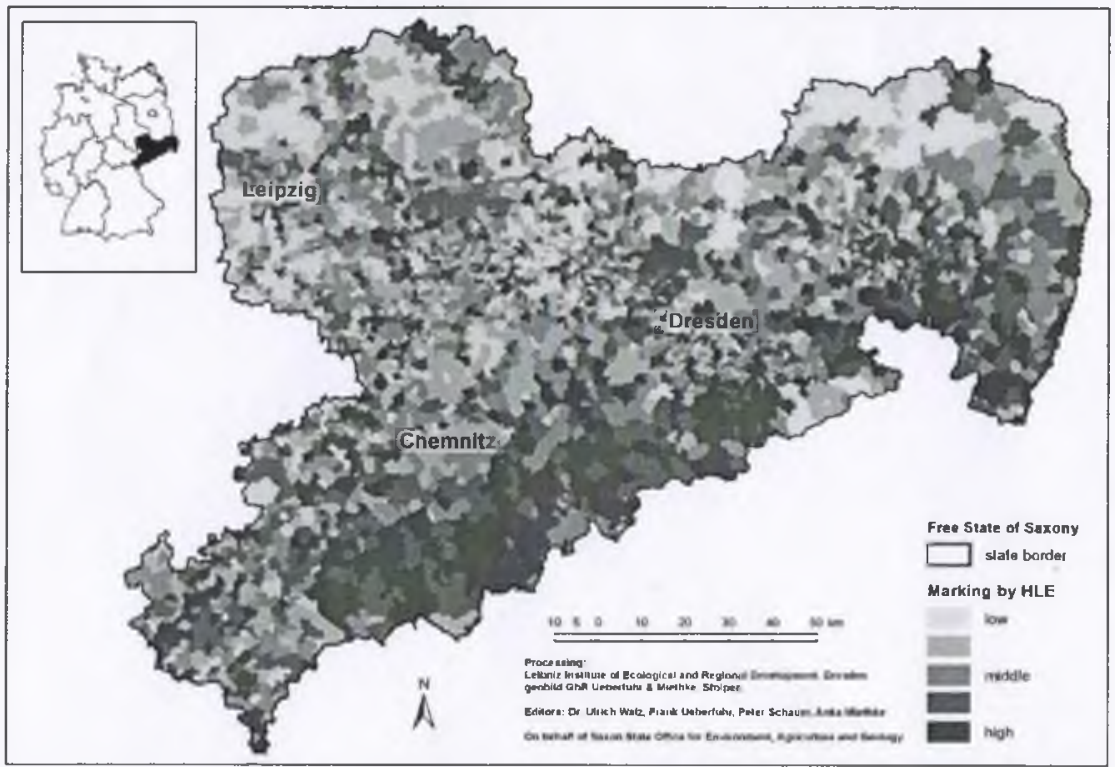

Fig. 2 Landscape units in Saxony (Germany), designated according to the presence and impact of Historical Landscape Elements (HLEs) in $5^{\circ}$ (Source: Walz et al. 2010)

Case study 4: Agro-environmental measures in a landscape plan

In a study of a rural municipality in Saxony (Germany). the economic opportunities/benefits were compared with possible income losses to farmers due to the nature conservation measures proposed under the landscape plan, using a calculation of variable margins before and after the (hypothetical) implementation of the plan (Lütz and Bastian 2002; Bastian et al. 2006b). The goals and measures proposed were tailored to the peculiarity of the landscape under consideration. The variable margin is: agricultural yield (sum of markelprices, subsidies and incentives, less production costs). The results indicated that most of the measures proposed by the landscape plan (such as planting hedgerows, reduction of land use intensity. establishment of field margins rich in arable weeds) - which are necessary to protect biodiversity and enhance the supply of ES (or LS) — could be realized without loss of income to farmers, if specific public subsidies from agro-environmental programmes were used. The subsidies encourage the farmers to support the delivery of specific LS on their land.

Case study 5: Landscape management accounting

To ensure that ecosystems and landscapes are able to provide services permanently, targeted landscape management is necessary, which entails financial expenditure by society. Landscape management is defined as the totality of all measures for the safeguarding, maintenance and development of natural habitats for indigenous species of plants and animals. and for the maintenance and renaturalization of ecosystems and landscapes in the event of damage (Jedicke 1996). As for example Hodder et ai. (2014) could show, landscape-scale conservation management leads in most cases to an overall increase in service provision. 


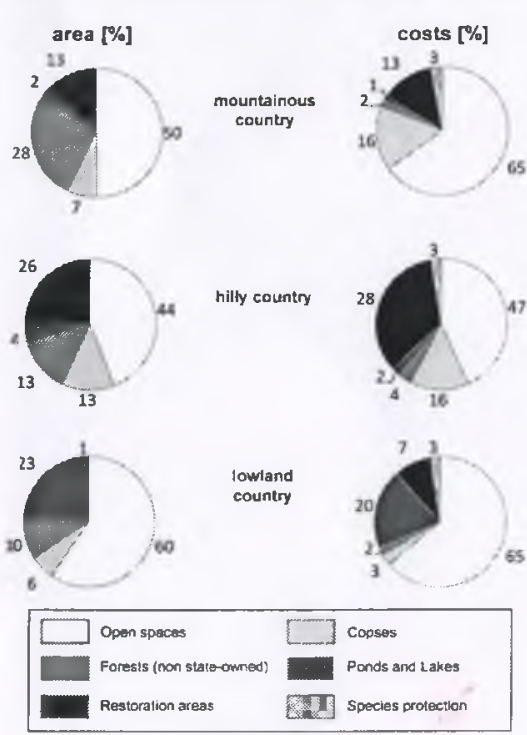

Fig. 3 Areas and costs of habitat/landscape management in the nature regions of Saxony (needs, referring to the area of each region; forest costs only for non-state owned areas)

The landscape management accounting system provides a practically valuable aid for political decisionmakers. It describes indicators, measures and pattems of behaviour for the achievement of such goals, taking the costs and available resources into account. It provides an estimation of the annual financial expenditure which will be required for implementation. Indicators for the accounting of landscape management measures and costs were assessed on the basis of landscape units (in addition to administration units, for details see Grunewald et al. 2014)

Areas and cost shares of landscape management tasks are shown in Fig. 3 for the three large natural regions of Saxony, each of which includes several landscape units.

Open country habitats, ponds and some types of forests and copses are biotope categories that need regular maintenance. Additionally, in restoration areas (lost) biotopes should be (re-)established. "Species protection" means areas where specific measures (e.g. nesting aids) for protected/endangered species are necessary.
The results of the case study (Grunewald et al. 2014) showed among others, that:

- some focal landscape units within Saxony require extensive restructuring measures with above-average costs.

- depending on the specific landscape character and the different occurrence of species, biotope types, ecosystems and/or landscape elements in these units, the amount of areas to be managed and, consequently, the costs are varying.

The monetary expense needed to maintain or improve the state of the landscape and its capacity to provide services may be seen as a minimum indicator of the appreciation of the ecosystems and the landscape concerned. Society or at least the decision makers are prepared to bear the costs to maintain the relevant ecosystems and landscape elements and the services they provide. The landscape management accounting system is a proxy method of ES valuation which reflects the imponance of ecological service categories and the valuation of those services across management options (Farber et al. 2006). The annual financial expenditure describes the maintenance costs, but the value of ES for society may differ in the sense, that the investment in management costs can be overcompensated by the revenues one gains from ES. The costs which arise in the implementation of these measures can be considered as indicators of the need for action to maintain ecosystems (Polasky et al. 2008).

\section{Synthesis}

Going beyond the theoretical considerations of the previous sections, Table 2 reflects the attempt to answer the question of whether and under what conditions an ES may be defined as LS. The assessment takes the form of an expert judgement by the authors, based on long-term experiences in landscapeecological and landscape planning issues. The involvement of other experts may modify the results in future. We distinguished between three levels:

- Low or no (1): The service refers only to a low degree to spatial aspects (e.g. the size or the pattern of the ecosystems or landscape elements), the specific landscape character, or the service is delivered by real ecosystems, not by such landscape elements, which are no ecosystems. 


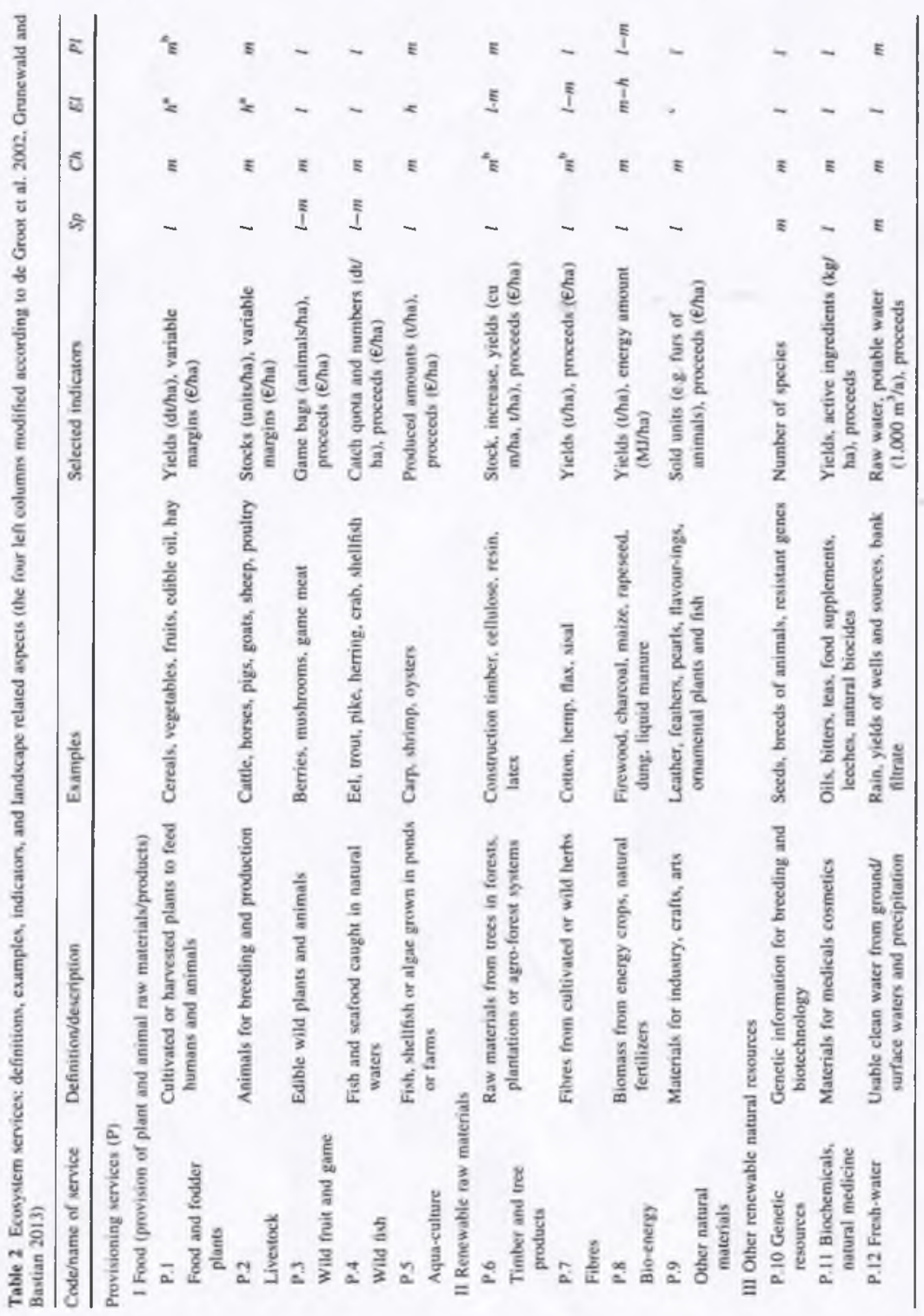


Table 2 continued

\begin{tabular}{|c|c|c|c|c|c|c|c|}
\hline Code/name of scrvice & Definition/descriplion & Examples & Selected indicators & $S p$ & $C h$ & $E t$ & $P l$ \\
\hline \multicolumn{8}{|l|}{ Regulation scrvices (R) } \\
\hline \multicolumn{8}{|c|}{ I Mcteorological services } \\
\hline $\begin{array}{l}\text { R.I } \\
\text { Air quality } \\
\text { regulation }\end{array}$ & Air exchange and cleaning & Filtering (fine dust, aeroscls), axygen supply & $\begin{array}{l}\text { Proportion of foresis (\%), leaf } \\
\text { arca index }\end{array}$ & $l$ & $m$ & $l$ & $h$ \\
\hline $\begin{array}{l}\text { R.2 } \\
\text { Climate } \\
\text { regulation }\end{array}$ & $\begin{array}{l}\text { Impacts on climatic processes and } \\
\text { extreme weather conditions }\end{array}$ & $\begin{array}{l}\text { Cold air and moisture supply, balancing } \\
\text { extreme temperatures and storms }\end{array}$ & $\begin{array}{l}\text { Propoltion of forests and } \\
\text { waters }(\%) \text {, slope }\left({ }^{\circ}\right) \text {, albedo }\end{array}$ & $m$ & $m$ & $l$ & h \\
\hline $\begin{array}{l}\text { R.3 } \\
\text { Carbon seques- } \\
\text { tration }\end{array}$ & $\begin{array}{l}\text { Removal of } \mathrm{CO}_{2} \text { from atmosphere and } \\
\text { storage in sinks }\end{array}$ & Fixation in soils. vegetation and oceans & $\begin{array}{l}\text { Proportion of vegetation areas } \\
\text { (\%), seil types (moors) }\end{array}$ & $l$ & $m$ & $I$ & 1 \\
\hline $\begin{array}{l}\text { R.4 } \\
\text { Noise protection }\end{array}$ & $\begin{array}{l}\text { Reducing noise through vegetation } \\
\text { and relief }\end{array}$ & Noise reducing effects of hills and woods & $\begin{array}{l}\text { Vitality, layers and density of } \\
\text { vegetation }\end{array}$ & $h$ & $m$ & $l$ & $m$ \\
\hline \multicolumn{8}{|c|}{ Il Hydrological services } \\
\hline $\begin{array}{l}\text { R.5 } \\
\text { Water regulation }\end{array}$ & $\begin{array}{l}\text { Balancing or avoiding loods, } \\
\text { droughts, fires and storm surges }\end{array}$ & $\begin{array}{l}\text { Natural irrigation, storagc in soils, } \\
\text { infiltration/groundwater recharge }\end{array}$ & $\begin{array}{l}\text { Slope }\left({ }^{\circ}\right) \text {, land use/cover }(\%) \text {, } \\
\text { soil classes }\end{array}$ & h & $m$ & 1 & $h$ \\
\hline $\begin{array}{l}\text { R. } 6 \\
\text { Water purification }\end{array}$ & $\begin{array}{l}\text { Filiration, nutrient fixation, waste } \\
\text { decomposition }\end{array}$ & $\begin{array}{l}\text { Self-purification of running and standing } \\
\text { waters }\end{array}$ & $\begin{array}{l}\text { Land use classes }(\%) \text {, soil } \\
\text { classes, morpholegy of } \\
\text { waters, riverside stripes }(\%)\end{array}$ & $m$ & $m$ & $l$ & $h$ \\
\hline \multicolumn{8}{|c|}{ III Pcdological services } \\
\hline $\begin{array}{l}\text { R.7 } \\
\text { Erosion } \\
\text { prevention }\end{array}$ & $\begin{array}{l}\text { Soil retention against water/wind } \\
\text { erosion, capping sedimentation }\end{array}$ & $\begin{array}{l}\text { Prevention of/protection from drifts, } \\
\text { landslides, }\end{array}$ & $\begin{array}{l}\text { Slope }\left(^{\circ}\right) \text {, land use, permanent } \\
\text { soil cover, crop spectrum }\end{array}$ & $m-h$ & $m$ & $l$ & $h$ \\
\hline $\begin{array}{l}\text { R. } 8 \text { Maintenancc } \\
\text { of soil fertility }\end{array}$ & $\begin{array}{l}\text { Regeneration of soil quality (soil } \\
\text { formation, nutricnt cycles, edaphon) }\end{array}$ & $\begin{array}{l}\text { Nitrogen fixation, waste decomposition, } \\
\text { humus formation/accumulation }\end{array}$ & Soil classes, crop diversity & 1 & $m$ & $l$ & $m$ \\
\hline \multicolumn{8}{|c|}{ IV Biological services (habitat functions) } \\
\hline $\begin{array}{l}\text { R.9 Regulation of } \\
\text { pests and } \\
\text { diseases }\end{array}$ & $\begin{array}{l}\text { Diminishing influences on rests and } \\
\text { epidemics }\end{array}$ & $\begin{array}{l}\text { Songhirds, lady-birds, laccwings, Anopheles } \\
\text { mosquitos (malaria), tics (encephalitis) }\end{array}$ & $\begin{array}{l}\text { Naturalness and vitality of } \\
\text { vegetation, species spectrum } \\
\text { (parasites, predators. pests) }\end{array}$ & $h$ & $m$ & $l$ & $l$ \\
\hline R. 10 Pollination & $\begin{array}{l}\text { Distribution of pollen and seeds of } \\
\text { wild and cultivated plants }\end{array}$ & Honcy and wild hees, bumblehees, hoverflies & $\begin{array}{l}\text { Share of (semi-) natural } \\
\text { vegetation (\%), flowering } \\
\text { plants, biocide application }\end{array}$ & h & $m$ & $l$ & $l$ \\
\hline $\begin{array}{l}\text { R.11 Conserving } \\
\text { biodiversity }\end{array}$ & $\begin{array}{l}\text { Providing living conditions/habitats } \\
\text { for native species, crops and breeds }\end{array}$ & $\begin{array}{l}\text { Animal and plant habitats. nursery places } \\
\text { (e.g. spawning sites) }\end{array}$ & $\begin{array}{l}\text { Naturalness of vegetation, } \\
\text { siructural diversity. biotope } \\
\text { networks, numbers of } \\
\text { species/breeds }\end{array}$ & $h$ & $m$ & $l$ & $h$ \\
\hline
\end{tabular}

\begin{tabular}{|c|c|c|c|c|c|c|c|}
\hline Code/name of service & Definition/dcscription & Examples & Selected indicators & $S p$ & $\mathrm{Ch}$ & $E l$ & $P l$ \\
\hline \multicolumn{8}{|l|}{ Socio-cultural services } \\
\hline \multicolumn{8}{|c|}{ I Psychological goods and services } \\
\hline $\begin{array}{l}\text { C. } 1 \\
\text { Ethical, spiritual. } \\
\text { rcligious values }\end{array}$ & $\begin{array}{l}\text { Harmony with naturc. intcgrity of } \\
\text { creation, autonomy of decision. } \\
\text { faimess (c.g. among generations) }\end{array}$ & Bioproducts, sacred places & $\begin{array}{l}\text { (Semi-) natural vegetation (\%), } \\
\text { extinct/threatened species. } \\
\text { genetically modified } \\
\text { organisms (GMO) }\end{array}$ & 1 & $l-h$ & $1-m$ & 1 \\
\hline C.2 Acsthetic valucs & $\begin{array}{l}\text { Diversity, identity, beauty, naturalness } \\
\text { of naturc and landscape }\end{array}$ & $\begin{array}{l}\text { Flowering meadows, harmonious } \\
\text { landscapc }\end{array}$ & $\begin{array}{l}\text { Land use, vegetation types, } \\
\text { crop and relief diversity }\end{array}$ & $h$ & $h$ & $1-h$ & $h$ \\
\hline $\begin{array}{l}\text { C.3 } \\
\text { Identificatiom }\end{array}$ & $\begin{array}{l}\text { Opportunities for personal attachment } \\
\text { and sense of home in landscapes }\end{array}$ & $\begin{array}{l}\text { Natural/cultural heritage, places of } \\
\text { remembrance, traditional knowledge }\end{array}$ & $\begin{array}{l}\text { Natural/cultural monuments, } \\
\text { historic landscape clements, } \\
\text { persistence/continuity of } \\
\text { landscape }\end{array}$ & $m$ & $h$ & $\boldsymbol{h}$ & $h$ \\
\hline C.4 Recreation & $\begin{array}{l}\text { Opportunities for sports and recreation } \\
\text { activities in nature and landscape }\end{array}$ & Accessibility, visual stimuli & $\begin{array}{l}\text { Naturalness, attractive species, } \\
\text { loadability, watcrs, snow } \\
\text { cover. number of visitors }\end{array}$ & $h$ & $h$ & $l-m$ & h \\
\hline \multicolumn{8}{|l|}{ II Information services } \\
\hline $\begin{array}{l}\text { C.5 Education and } \\
\text { training }\end{array}$ & $\begin{array}{l}\text { Opportunitics for knowledge gain, } \\
\text { scientific research and technical } \\
\text { innovations }\end{array}$ & $\begin{array}{l}\text { Natural snil profiles, functioning } \\
\text { ecosystems, rare species }\end{array}$ & $\begin{array}{l}\text { Natural and cultural } \\
\text { monuments, diversity of } \\
\text { ccosystems and land use } \\
\text { forms, naturalness }\end{array}$ & $m$ & $m$ & $l-h$ & $m$ \\
\hline $\begin{array}{l}\text { C.6 Intellectual and } \\
\text { artistic inspiration }\end{array}$ & $\begin{array}{l}\text { Stimulating fantasy and inventive } \\
\text { talent, inspiration for architecture, } \\
\text { painting/photography, music, } \\
\text { fashion and folklore }\end{array}$ & $\begin{array}{l}\text { limpressive landscapes, mountains, cliffs, } \\
\text { floodplains, old trees }\end{array}$ & Landscape elements, species & $h$ & $h$ & $l-h$ & $h$ \\
\hline $\begin{array}{l}\text { C.7 Environmental } \\
\text { indication }\end{array}$ & $\begin{array}{l}\text { Recognizing environmental } \\
\text { conditions, loads and changes } \\
\text { through visible structures, processes } \\
\text { and species }\end{array}$ & $\begin{array}{l}\text { Indication with lichens (air quality), } \\
\text { indicator plants (site conditions) }\end{array}$ & $\begin{array}{l}\text { Species spectrum (ecological } \\
\text { groups), test organisms }\end{array}$ & $m$ & $m$ & $l$ & 1 \\
\hline $\begin{array}{l}\text { C.8 } \\
\text { Archive function }\end{array}$ & $\begin{array}{l}\text { Documenting the history of nature and } \\
\text { landscape }\end{array}$ & $\begin{array}{l}\text { Relictic soils, historical landscape } \\
\text { elements }\end{array}$ & Rclevant sites or elements & 1 & $m$ & $l-h$ & $m-h$ \\
\hline
\end{tabular}


- Medium (m): Spatial aspects or the landscape character usually play a medium role for the service. The service may be delivered both by ecosystems and other landscape elements. Its significance for landscape planning is medium or case specific

- High (h): The service depends to a high degree on spatial aspects or the landscape character. It refers more to landscape elements, which are not necessarily ecosystems, or the relevance for landscape planning is high.

The table show the following facts:

Sparial aspects: The relevance for provisioning services is mostly rather low. The same is true of carbon sequestration and maintenance of soil fertility. Yields in agriculture. for instance, mainly depend on specific site conditions of a field plot (nutrient and water supply), not so much on spatial patterns or connectivity. Carbon sequestration provides benefits (reduced $\mathrm{CO}_{2}$ in the atmosphere) for the whole mankind, not only for the limited area where it takes place. Several regulation and socio-cultural services show medium to high relevance, especially protection against noise (e.g. vegetation structures between roads and settlements), water regulation (structure of the catchment), pollination (bee habitats near the farmland), conserving biodiversity (minimum areas, habitat networks), aesthetic values, and recreation (size and pattern of forests).

Landscape characier: This totality of characteristics of an area is important for many ES, for the growth of plants and animals and for other provisioning services, but also for the majority of regulation services. We assigned a medium level of relevance to both the provisioning and regulation services. Landscape character is very important for various socio-cultural services, particularly aesthetics, inspiration, and recreation.

Landscape elements are more important than ecosystems as reference objects for provisioning services from farm fields (land use dominance, non-natural ecosystems), and also for some socio-cultural services (e.g. identification with a region and inspiration do not refer to ecosystems only, but also to other, among them, historical landscape elements - Table 1).

Relevance for landscape planning is low for provisioning services, because landscape planning is not economic planning, but rather sectoral planning for nature conservation and landscape management The relevance for regulation services is higher, with respect to the assets to be protected (soil, waters, local climate, biodiversity). There is also a high relevance for socio-cultural services, particularly for aesthetic values, recreation, identification and inspiration.

None of the services listed in the tables may be identified absolutely as ES or LS; rather, their categorization depends on the object of reference (on the supply side): Is the service provided by an ecosystem, a landscape element or a whole landscape/? Accordingly, the adequate indicators and assessment methods can be specified. The demand side is less important, because ecological reference units (including landscapes) play a minor role compared with, for instance, administrative units. We argue that almost all ES can also be considered as LS, if the spatial aspects and the planning and management context are emphasized and if they explicitly refer to landscape elements, landscape units or the landscape character. There are no differences as to service classification: both ecosystem and landscape may supply provisioning, regulation and socio-cultural services.

\section{Discussion and conclusion}

The concepts ES and LS overlap to some degree, but they are not identical. We present no arguments in favour of replacing ES by LS, but we do prefer a situation-related use of both terms. We do not share the opinion that landscape is only and absolutely a theoretical construct, as advanced by Kirchhoff et al. (2012), who argued that the terms landscape and ecosystem designate categorically distinct phenomena: the former an aesthetic construct associated with symbolic meanings and specific cultural values, the latter a material system of interacting biotic and abiotic entities, to which such utility values as provisioning, regulating and supporting ES are attached

Taking the literature review and the own studies into consideration, we can note that, compared to ES, LS show the following special features, which have been addressed only partly by Termorshuizen and Opdam (2009) and others: They

- are strongly related to landscapes and landscape elements rather than to ecosystems 
- broaden the perspective beyond the services closely linked to ecosystems, and place more emphasis on aesthetic, ethical and other socio-cultural aspects than ES do (with the exception of socio-cultural ES).

- express a stronger reference to spatial characteristics, e.g. the configuration of ecosystems and land use units in spatial, structural and process-related interactions (pattern-process relationships), the consideration of neighbouring effects, and the spatial position of service supply and demand.

- are more strongly focused on anthropogenic effects (e.g. land use), as the term "landscape" explicitly includes the interplay between humans and their environment, while ecosystem represents the relationships between a biocoenosis and its habitat or environment.

- suppon a more integrative view, e.g. the linkage of the social concept of space (space of perception and space of action) with the physical concept of space (e.g. ecosystem complex), and emphasize the total character of an area (landscape peculiarity).

- use landscapes as spatial reference units, which simplify the understanding of the complex interrelationships of characteristic conditions in different areas.

- bring various scientific disciplines together, because aspects of nature, culture and land use are addressed equally, although the individual scientific disciplines use different landscape definitions.

- are more relevant to the practice of landscape planning and landscape management, and encourage communication and participatory approaches (landscape as "a unifying common ground").

It may sound trivial, but the decisive difference between ES and LS is the object they refer to: ES to ecosystems, LS to landscapes and landscape elements (which need not to be necessarily ecosystems). We distinguish between three cases:

1. The service is supplied by ecosystems, landscape issues do not play a considerable role $\rightarrow$ There is no necessity for the term LS.

2. The service is supplied by ecosystems, but also landscape issues are important (e.g., landscape character, landscape units) $\rightarrow$ Both the terms ES and LS may be used (see case studies 1, 2, 4 and 5).

3. The service is not supplied by an ecosystem but by other landscape elements. Here, the term ES would be obsolete, and instead of ES the term LS should be used (see case study 3 ).

LS are not the same as socio-cultural ES. In the present paper, the physical landscape concept (as a complex of ecosystems and creations of humans, among them landscape elements, which are not ecosystems) were in the centre. The relations between constructivist landscape concepts and ES (or LS) concepts need further investigation. Schaich et al. (2010) argue for a closer link between the cultural landscape research and ES research that would enrich and possibly sharpen both approaches. In particular, landscape research on cultural services such as aesthetics or cultural heritage could provide valuable results and methods for a comprehensive assessment of ES. Accordingly, Tengberg et al. (2012) address the advantages of better linking the concepts of heritage values and identity as used by the ES research community and the concepts of heritage, landscape memory, history and identity as used by the cultural landscape research community.

A further question is whether there are special tools for the assessment of LS. Obviously the assessment methods for both ES and LS are partially similar or even identical. Due to the broader multidisciplinary approach of LS, a more comprehensive methodological spectrum of scientific competencies and methods can be considered. The methods for the assessment of LS (supply side) essentially derive from landscape ecology, particularly if we refer to physical landscape. The demand side, however, and the combination of both the supply of and demand for LS have not yet been elaborated. Consequently, there is also a lack of comprehensive, consistent frameworks for LS. Such a framework should incorporate knowledge and components from all disciplines involved, both from scientific (e.g. geography, landscape ecology) and the application disciplines (e.g. landscape planning).

Syrbe and Walz (2012) have noted some methodological steps of a landscape-related service assessment framework:

1. Determination of the spatial and temporal structure of the landscape (spatial arrangements of functional units, habitats, landscape elements and land use constraints) depends on the services demanded, especially the differentiation and delineation of Service Providing Areas (SPAs) and Service Benefiting Areas (SBA), and also of Service Connecting Areas (SCA), if useful. 
2. Determination of potential services independently of actual use (according to the concept of potentials-Bastian et al. 2012b).

3. Addressing the stakeholders, actors and beneficiaries in particular for service valuation in the landscape planning or landscape govemance contexts.

Finally, the question of how LS are to be defined remains. Precise definitions are largely or entirely absent in the relevant literature. One exception is Willemen (2010), who defined LS as "the flow of goods and services provided by the landscape to society". Syrbe and Walz (2012) considered the term ES synonymous with LS in general, but used the latter to emphasize spatial relationships. Wu (2013) defined landscape services as "ecosystem services provided by multiple landscape elements in combination as emergent properties". This narrow definition of LS refers to ecological services generated by landscape pattern or configuration. His broad definition of LS includes all ecological services generated by individual ecosystems (or land cover types) and their spatial combinations at the landscape scale (Wu 2013).

For Termorshuizen and Opdam (2009) LS is a specification, rather than an alternative, to ES "when striving for development of an interdisciplinary science base for collaborative landscape development."As landscapes may have a wide range of dimensions, from small mosaics of landscape elements on the local scale to large, regional-scale areas, we firmly believe that it is not enough to speak about the "landscape scale", or the application of the ES approach at "the" landscape level, and thus to associate with this term a specific size of the study area (e.g. Muller et al. 2010; de Groot et al. 2010), or to limit LS to medium scales, whereas ES would comprise all scales, from a square metre to a continent (Kienast 2010).

Basing on the theoretical considerations and the case studies presented in this paper, we propose the following definition: Landscape services are the contributions of landscapes and landscape elements to human well-being.

Acknowledgments We thank the micwers and the editor, Prof. 1. Wu, for their helpful comments and comprehensive advices, but also Mr. Phil Hill. Berlin, for polishing the language.

\section{References}

Alber C, von Haaren C, Galler C (2012) Okosystemdienstleistungen. Alter Wein in ncuen Schlauchen oder cin Impuls fur die Landschaftsplanung? Naturschutz und Landschaftsplanung 44: 142-148

Antrop $M(2000)$ Changing patterns in the urbanized country side of Westem Europe. Landscape Ecol 15:257-270

Baja S. Chapman DM. Dragovich D (2002) A conceptual model for defining and assessing land management units using a fuzzy modeling approach in GIS environment. Environ Manag 29:647-66!

Bastian $O$ (2008) Landscape classification: between fact and fiction. In: Lechnio J, Kulczyk S, Malinowska E, Szumacher 1 (eds) Landscape classification. Theory and practice. Warsaw University, pp 13-20

Bastian O. Kronen R. Lipsky Z (2006a) Landscape diagnosis in different space and time scales - a challenge for landscape planning. Landscape Ecol 21:359-374

Bastian O. Lutz M, Roder M, Syrbe R-U (2006b) The assess ment of landscape scenarios with regard to landscape functions. In: Meyer BC (ed) Sustainable land use in intensively used agricultural regions. Landscape Europe. Alterra Rep. No. 1338, Wageningen. pp 15-22

Bastian O. Grunewald K. Syrbe R-U (2012a) Space and timc aspects of ecosystem services, using the example of the EU Water Framework Directive. Int J Biodivers Sci Ecosyst Serv Малаg 8(1-2):5-16

I Bastian O, Haase D. Gruncwald K (2012b) Ecosystem properties, potentials and services - the EPPS conceptual framework and an uman application example. Ecol Indic 21:7-16

Bastian O. Lupp G, Syrbe R-U, Steinhâuler S (2013a) Ecosystem services and energy crops-spatial differentiation of risks. Ekologia Bratislava 32:13-29

- Bastian O. Walz U, Decker A (2013b) Historical landscape elements: pant of our cultural heritage-a methodological study from Saxony. In: Kozak J, Ostapowicz K, Bytnerowicz A. Wyzga B (eds) Intcgrating nature and socicty towards sustainability. Environmental Science and Engincering. Springer. Bcrlin Hcidelberg, pp 441-460

Blaschke T (2006) The role of the spatial dimension within the framework of sustainable landscapes and natural capital. Landsc Urb Plan 75:198-226

Botcquilha Leitao A. Miller J, Ahern J, McGarigal K (2006) Measuring landscapes: a planner's handbook. Island Press. Washington, DC

Burggraaff P. Klecfeld K-D (1998) Historische Kulturlandschaft und Kulturlandschaftsclemente. Angewandtc Landschaftsokologic 20:320

Burkhard BF, Müller F, Windhorst W (2009) Land scapes capacities to provide ecosystem services-a concept for land-cover based assessments. Landsc Online 15:1-22

CBD-Convention on Biological Biodiversity (2010) Global Biodiversity Outlowk 3. CBD Secretariat, Montreal

Costanza R (20)8) Ecosystem services: multiple classification systems are needed. Biol Conserv 141:350-352 
Daricl TC (2001) Whither scenic beauty? Visual landscape quality assessment in the 2 t th century. Landsc Urb Plan 54:267-281

De Groot RS, Wilson M. Boumans R (2002) A typology for description, classification and valuation of ecosystem functions, goods and services. Environ Econ 41:393-408

De Groot RS, Alkemade R, Braat L. Hein L, Willemen L (2010) Challenges in integrating the concept of ecosystem services and values in landscape planning. management and decision making. Ecol Complex 7:260-272

Ellenberg H (1973) Die Okosysteme der Erde: Versuch einer Klassifikation der Okosysteme nach funktionalen Gesichtspunkten. In: Ellenherg $\mathrm{H}$ (ed) Okosystemforschung Springer, Berlin Heidelberg New York, pp 235-265

Farher S, Costanza R, Childers DL. Erickson J, Gross K, Grove M. Hopkinson CS, Kahn J, Pincetl S, Troy A, Warren P. Wilson $M$ (2006) Linking ecology and economics for ecosystem management. Bioscience 56:117-129

/ Fisher B. Tumer RK, Morlin P (2009) Defining and classifying ccosystem services for decision-making. Ecol Econ $68: 643-653$

Frank S. Fürst C, Koschke L, Makeschin F (2012) A contribution towards a transfer of the ecosystem service concept to landscape planning using landscape metrics. Ecol Indic $21: 30-38$

Grunewald K. Bastian O (2010) Okosystemdienstleistungen analysieren-begrifflicher und konzeptioneller Rahmen aus landschaftsokologischer Sicht. Geo-Oko 31:50-82

Grunewald K. Bastian O (eds) (2013) Okosystemdienstleistungen. Konzept, Methoden und Fallbeispiele. SpringerSpektrum. Heidelberg Berlin (English edition: Ecosystem services. 2014)

Gruncwald K. Syrbe R-U, Renner C (2012) Analyse der âsthetischen und monetaren Wcrtschatzung der Landschaft am Erzgebirgskamm durch den Tourismus. Geo-Oko 33:34-65

Gruncwald K. Syrbe R-U, Bastian O (2014) Costs of landscape management measures as indicators of the value of ecosystem services - as exemplified by the Landscape Management Strategy of Saxony. Ecol Indic 37(A):241-25

Gunzelmann T (1987) Die Erhaltung der historischen Kulturlandschaft. Angewandte historische Geographie des landlichen Raumes mit Beispiclen aus Franken. Bamberger Wirtschaftsgeogr. Arbeiten 4, Bamberg, pp 318

Haase G, Mannsfeld K (cds)(2002) Naturraumeinheiten, Landschaftsfunktionen und Leitbilder am Beispiel von Sachsen. Forschungen zur deutschen Landeskunde 250. Flensburg

Hein L, van Koppen K, de Groot RS, van Icrland EC (2006) Spatial scales, stakcholders and the valuation of ecosysicm scrvices. Ecol Econ 57:209-228

Heinz Center-The H. John Heinz (III) Center for Science. Economics and the Environment (2008) Landscape pattern indicators for the nation: a report from the Heinz Center's landscape pattem task group, Washington, DC

Hodder KH. Newton AC, Cantarello E, Perrella L (2014) Docs landscape-scale conservation management enhance the provision of ecosystem scrvices? Int J Biodivers Sci Ecosyst Serv Manag 10(1):71-83

Jedicke E (ed) (1996) Praktische Landschaltspllege-Grundlagen und Maßnahmen, 2nd edn. Ulmer. Stuttgart
Kienast $F$ (2010) Landschaftsdienstleistungen: cin taugliches Konzept fur Forschung und Praxis? Forum fur Wissen. pp $7-12$

Kirchhoff $T$, Trepl L, Vicenzotti $\vee(2012)$ What is landscape ecology? An analysis and evaluation of six different conceptions. Landsc Res 38(1):33-51

+ Lang S. Walz U. Klug H, Blaschke T, Syrhe R-U (2009) Landscape metrics - a toolbox for assessing past, present and future landscape structure. In: Bender $\mathrm{O}$. Evelpido $\mathrm{N}$, Krck A. Vassilopoulos A (eds) Gcoinformation technologies for geocultural landscapes. European Perspectives, CRC Press, Boca Raton. pp 207-234

Leibenath M. Gailing L (2012) Scmantische Annaherung an die Woric "Landschaft"und ...Kulturlandschaft". In: Schenk W, Kuhn M. Leibenath M, Tzschaschel S (eds) Suburbane Raume als Kulturlandschaften. Verlag der ARL. Hannover, pp 58-79

Leser H (1997) Landschaftsokologic. 4th ed, UTB. Ulmer, Stuttgart (1st ed 1976)

Lupp G, Albrecht J, Darbi M. Bastian O (2011) Ecosystem services in energy crop production - a concept for regulatory measures in spatial planning? J Landscape Ecol 4:49-66

Lupp G, Syrbe R-U. Steinhaußer R. Bastian O (2014) Perception of energy crops by laypersons and farmers using the approach of ecosystem services. Moravian Geogr Rep

Lutz M, Bastian $O$ (2002) Implementation of landscapc planning and nature conservation in the agricultural landscape-a case study from Saxony. Agric Ecosyst Envirun 92:159-170

MEA-Millennium Ecosystem Assessment (2005) Ecosystems and human well-being. Synthesis. Island Press, Washington, DC

Vuller F, de Groot R, Willemen L (2010) Ecosystem services at the landscape scale: the need for integrative approaches. Landsc Online 23:1-11

Neef E (1976) Nebenwirkungen der gesellschaftlichen Tätigkeiten im Naturraum. Pctcrnanns Geogr Mitt 120:141-144

Palang H. Printsmann A. Konkoly Gyuro E. Ubanc M. Skowronek E. Woloszyn W (2006) The forgotten rural landscapes of Central and Eastern Europe. Landscape Ecol $21: 347-357$

Plieninger T. Bieling C. Gerdes H, Ohnesorge B, Schaich H, Schleyer C, Trommler K, Wolff F (2010) Okosystemdienstleistungen in Kulturlandschaften. Konzept und Anwendung am Beispicl der Biospharenreservate Oherlausitz und Schwahische Alh. Natur und Landschaft 85:187-192

Polasky S, Nelson E, Camm J, Csuti B. Fackler B. Lonsdorf F Montgomery C, White D, Arthur J. Gaber-Yonts B. Hai ght R, Kagan J, Starfield A, Tobalske C (2008) Where to put things? Spatial land management to sustain biodiversity and economic returns. Biol Conserv 14t:1505-1524

Ring 1. Hansjürgens B, Elmqvist T. Wittmer H. Sukhdev P (2010) Challenges in framing the economics of ecosystems and biodiversity: the TEEB initiative. ScienceDirect. Cur Opin Environ Sustain 2:15-26

Rosenberg M, Syrte R-U, Vowinckel J. Walz U (20|4) Scenario methodology for modelling of furure landscape develop ments as basis for assessing ecosystem services. Landsc Online $33: 1-20$ 
Schaich H. Bicling C, Plieninger T (2010) Linking ecosystem services with cultural landscape research. Gaia 19:269-277

Syrbe R-U, Walz U (2012) Spatial indicators for the assessment of ecosystem services: providing. benefiting and connecting areas and landscape metrics. Ecol Indic 21:80-88

Tengberg A, Fredholm S, Eliasson I, Knez I. Saltzman K, Wetterberg $\mathrm{O}(2012)$ Cultural ecosystem services provided by landscapes: assessment of heritage values and identity Ecosyst Serv 2:14-26

Termorshuizen JW, Opdam P (2009) Landscape services as a bridge between landscape ecology and sustainable development. Landscape Ecol 24:1037-1052

The Countryside Agency + Scottish Natural Heritage (2002) Landscape character assessment: guidance for England and Scotland. Sheffield, pp 84

Treit M. Ode A. Fry G (2006) Key concepts in a framework for analysing visual landscape character. Landsc Res 31:229-255

Uuemaa E. Antrop M, Ronsaare J, Marja R, Mander U (2009) Landscape melrics and indices: an overview of their use in landscape research. Living Rev Landsc Res 3:1-28

Vandewalle M, Sykes MT. Harrison PA, Luck GW, Berry P, Bugter R, Dawson TP, Feld CK, Harrington R, Haslet JR. Hering D, Jones KB, Jongman R, Lavorel S, Martins da Silva P. Moora M. Paterson J. Rounsevell MDA, Sandin L. Scttelc J, Sousa JP. Zohel M (2008) Review paper on concepts of dynamic ecosystems and their services. RUBICODE Deliverable D2.I. Available from http://www.
rubicode.ne/rubicode/RUBICODE e-conference report. puf. Accessed Dec 2013

vor Haaren C (cd) (2004) Landschaftsplanung. UTB, Ulmer, Stutgart

Walz U (2008) Monitoring of landscape change and functions in Saxony (Eastem Germany) - methods and indicators. Ecol Indic 8:807-8:7

f. Walz U (2011) Landscapc structure, landscape metrics and biodiversity. Living Rev Landsc Res 5:1-35

Walz U, Uebcrfuhr F, Schauer P, Halke E (2010) Ableitung und Bcwertung von Kulturlandschaftsgebieten fur das Landschaftsprogramm Sachsen. Natur und Landschaft 85:17-23

Vascher DM (ed)(2005) European landscape character areastypologies, cartography and indicators for the assessment of sustainable landscapes. Alterra Report 1254. Wageningen

Wende W, Wojtkiewicz W, Marschall I, Heiland S, Lipp T, Rcinke M. Schaal P. Schmidt C (2012) Putting the plan into practice: implementation of proposals for measures of local landscape plans. Landsc Res 37:483-500

Willemen L (2010) Mapping and modeling multifunctional landscapes. PhD thesis, University of Wageningen, Wageningen

Willemen L, Veldkamp A, Verhurg PH, Hein L, Lcemans $\mathbf{R}$ (2012) A multi-scape modelling approach for analysing landscape service dynamics. J Environ Manag 100:86-95

$\bigvee$ Wu JG (2013) Landscape sustainability science: ecosystem services and human well-being in changing landscapes. Landscape Ecol 28:999-1023 
